\title{
Corporate Influence in World Bank Lending
}

\author{
Rabia Malik, New York University Abu Dhabi \\ Randall W. Stone, University of Rochester
}

The World Bank withholds loan disbursements in order to build a reputation for enforcing conditionality, and multinational firms lobby for these funds to be released. Using data drawn from World Bank reports, we find evidence that (1) participation by Fortune 500 multinational corporations as project contractors and (2) investments by these firms are associated with disbursements that are unjustified by project performance. In addition, these measures of corporate interest are associated with inflated project evaluations. These effects are limited to multinational corporations headquartered in the United States or Japan, suggesting that the influence of private actors depends on access to particular national policy networks. In contrast to the evidence of corporate influence, we find no consistent evidence of geopolitical influences.

M ultinational corporations (MNCs) profit from World Bank lending by serving as contractors and by enjoying the downstream benefits of development projects. Their interests diverge from those of the Bank, however, because the Bank is responsible for diverse mandates, such as environmental protection; it seeks to defend a global reputation, while firms are interested in the outcomes of individual projects. The Bank enforces conditionality by withholding funding from projects that come up short. Well-connected multinational firms, on the other hand, lobby to release these funds, which undermines the Bank's efforts to maintain project quality and pursue environmental and human rights mandates. This lobbying is effective because the World Bank is subject to substantial US and Japanese informal influence, democratic governments are responsive to corporate interests, and World Bank officials have professional incentives to exaggerate project performance.

Our conclusions may seem puzzling to readers familiar with contemporary models of foreign direct investment. Foreign investment is an attractive strategy for high-productivity firms, which can afford the fixed costs of locating abroad, and which have intangible assets to protect, and therefore prefer to invest rather than contract at arm's length (Helpman, Melitz, and Yeaple 2004). From this perspective, MNCs should be valuable partners for the Bank because the firms that engage in foreign direct investment (FDI) have technology, organi- zational skills, and other intangible assets that give them high productivity. Here, MNCs are allies in economic development: they should promote project performance and should not be particularly tempted to collude with governments or lobby on behalf of governments that fail to perform, because their interests are aligned with the Bank's.

The missing factor in this argument is firms' political activity. A large multinational firm is a potent political actor both in the host country, where it invests, and in the home country, where it has its headquarters. When it makes a foreign investment, it anticipates the political power that it will wield as a high-capacity organization with specific assets at risk. In some cases, these investments only make sense because of the opportunity to obtain rents, either through market imperfections or political activity. Firms investing with these motives are unlikely to be allies of the World Bank, and their investments may be predicated on the ability to subvert the Bank's intentions. This political economy perspective would not expect MNCs to improve project performance but would expect them to collude with Bank staff on project evaluation and lobby for disbursements of financing that may improve their own bottom lines.

From this perspective, the politics of implementing conditionality should be quite different in the World Bank than in its sister institution, the International Monetary Fund (IMF). The Bank is more attractive as a political target for multi-

Rabia Malik (rabia.malik@nyu.edu) is a postdoctoral associate in political science at New York University Abu Dhabi, PO Box 129188, Abu Dhabi UAE. Randall W. Stone (randall.stone@rochester.edu) is a professor of political science at the University of Rochester, Rochester, NY 14627.

Data and supporting materials necessary to reproduce the numerical results in the article are available in the JOP Dataverse (https://dataverse.harvard.edu /dataverse/jop). An online appendix with supplementary material is available at http://dx.doi.org/10.1086/694102. 
national firms, and the Fund is more attractive to powerful states. Individual IMF decisions can rescue or topple member governments, so states have strong incentives to maintain close control over decision making (Stone 2011). In contrast, while aggregate Bank lending is substantial, the implementation of most Bank projects involves lower political stakes, so the cost of devolving control over implementation to private agents is lower. From the perspective of firms, interests in IMF programs are diffuse and rarely tangible enough to justify political activity. In contrast, firms have interests in particular World Bank projects.

New project-level data that are more comprehensive and detailed than were previously available allow us to investigate the politics of project evaluation and implementation. We have coded all Implementation Completion and Results (ICR) reports for projects from 1994 to 2013 for project evaluations, sectoral composition, objectives, and implementation. We combine these data with firm-level data on participation in projects as contractors from the World Bank's records and on foreign mergers and acquisitions from Securities Data Company (SDC) Platinum. We find no evidence that MNC involvement as contractors improves the performance of Bank projects. However, we do find that participation by Fortune Global 500 multinational corporations as contractors is associated with increases in disbursement rates that are not justified by project performance, and with inflated project evaluations. We interpret this as evidence of corporate lobbying for disbursements and collusion by Bank staff to influence evaluation. This interpretation is corroborated by further tests that zero in on the mechanism of influence. The effect of contractors is strengthened when we focus on those with management functions, which have the strongest incentives to lobby. Furthermore, disaggregating contractors by country of origin shows that the results are driven by firms headquartered in the United States and Japan, which have access to the most influential policy networks. The implications of these results are expanded by further tests using an alternative measure, investments by these MNCs. While the contracts data provide clean identification of lobbying motives, the investment data suggest that the range of firms involved in political activity is broader than the set of contractors. In contrast, we do not find evidence of patterns of informal influence at the project level consistent with the kind of geopolitical motives that have been found in studies of the IMF and the Bank that have focused on country-level outcomes.

\section{THE POLITICAL ECONOMY OF PROJECT EVALUATION}

Three chains of delegation provide access points for MNCs that seek to influence the World Bank. First, the internal delegation chain from the Bank to its staff is based on its staff evaluation system. The criteria used to evaluate projects affect lending policy because project evaluations affect the personnel evaluations of project managers. Second, the Bank is an agent of its member states, which exert formal control through their executive directors and informal control through pressure on the Bank's management. The United States is the key principal. Among the other leading states, Japan has historically played a much stronger role in the Bank than in the IMF. A third chain of delegation lies within the governance structures of the major member states, which are democracies and therefore accessible to determined interest groups. The most significant changes in Bank policy began as lobbying campaigns by interest groups and NGOs, which almost always focused their efforts on mobilizing support in the US Congress. Similarly, exceptions to Bank policies, which are of more interest to particular MNCs than the general contours of policy, frequently originate in efforts to lobby the US government.

States use project evaluation criteria to control the World Bank, and nongovernmental actors seek to reform the criteria to influence the Bank's behavior. The Bank has been the target of several effective campaigns by NGOs to reform its policies (see Keck and Sikkink 1998). ${ }^{1}$ In each case, the mechanism of influence appeared to flow through national governments. For example, the World Bank adopted an environmental mandate under the McNamara presidency but made little progress for many years in improving environmental outcomes because no environmental criteria were included in project evaluations. Environmental interest groups publicized this failure in the 1980s and successfully lobbied for far-reaching changes in the Bank's policies for monitoring the environmental impact of its projects. The turning point appears to have been the successful effort to lobby the US government, which in turn used its position on the Executive Board and its informal influence with the management of the Bank to promote reform (Nielson and Tierney 2003).

An illustration of the importance of project evaluations to the careers of project managers, or task team leaders (TTLs), is that the Bank finds it difficult to find qualified staff who are willing to work in countries where project outcomes are unlikely to be favorable (Independent Evaluation Group 2006, 54). The World Bank Independent Evaluation Group (IEG) report, "Engaging with Fragile States," argued that country directors tended to neglect fragile states, where evaluation outcomes were not expected to be impressive, and concentrated their efforts on countries that appeared to be more promising.

1. Campaigns have led to changes in the Bank's operational manual covering involuntary resettlement (1980), indigenous peoples (1982), poverty reduction (1993), and gender issues (1994); each of these criteria has been incorporated into the process of project evaluation (Clegg 2013, 110). 
In its response to the evaluation, Bank management concurred with the IEG diagnosis, specifically repeating the point that incentives created by the process of staff evaluation made it difficult for the Bank to respond adequately to crises in fragile states (Independent Evaluation Group 2006, 57).

The sensitivity of project evaluations generates an incentive to present project outcomes in the most positive light, but this incentive is balanced by the IEG, which audits every project's implementation and completion report (ICR). ${ }^{2}$ The ICRs are self-assessments prepared by the TTLs and their staff, and the IEG evaluation disagrees with the ICR in approximately $20 \%$ of the cases and generally downgrades the evaluation when it disagrees. In addition, it rates 10\%-15\% of ICRs as "unsatisfactory."' A standard IEG review is a desk review based on the project documents and the ICR; in about one-third of the projects, the IEG also performs a Project Performance Assessment Report (PPAR), which is a more detailed evaluation that involves sending IEG personnel into the field to investigate outcomes. ${ }^{4}$ The ever-present incentive to shade the truth in a favorable direction when preparing the ICR is balanced by the risk of receiving a downgrade or an unsatisfactory rating for the ICR, which is professionally embarrassing and could influence staff performance evaluations. The seriousness with which IEG evaluations are taken is indicated by the vigorous defense mounted by staff whose projects receive negative assessments, particularly when there is a "disconnect" between the ICR evaluation and the IEG evaluation. $^{5}$

MNCs are generally uninterested in influencing the broad patterns of Bank policy but may be intensely interested in particular exceptions to these policies that affect their own profits. This can occur for two reasons. First, the majority of World Bank projects are performed in part or in whole by firms working on contracts, and many of these are affiliates of major MNCs. In these cases, the parent firm has a financial interest in seeing that the affiliate is paid for its services, and disbursement of funds may be delayed or canceled if the project is unsuccessful. All else equal, the TTL shares the firm's preference for full disbursement because this contributes to the overall outcome rating, but conditional on the

2. Formerly the Operations Evaluation Department (OED), established in 1973.

3. The burden of proof is on the project team, and if evidence of results is weak, the IEG may rate the ICR as unsatisfactory and downgrade the project outcome. Interview with Soniya Carvalho, IEG Lead Evaluation Officer, December 18, 2014.

4. The IEG has a staff of about 100 evaluators with diverse fields of expertise. Desk evaluations start with the loan documents and the ICR, and each evaluation goes through three levels of review.

5. Interview with Soniya Carvalho, December 18, 2014. project not fully achieving its objectives, the TTL can limit the damage by reducing disbursement. ${ }^{6}$ To the extent that multinational firms are able to effectively pressure the Bank to fully disburse the loans from which their affiliates benefit, this creates an additional incentive for project managers to exaggerate the extent to which project objectives were fulfilled in order to justify high disbursement rates.

Second, a firm may have an incentive to lobby for full disbursement even if it is not a direct recipient of project funds, because it does not internalize the benefits of the Bank's strategy of maintaining a reputation for enforcing conditionality. Suspending disbursement is the Bank's primary tool to incentivize governments to fulfill their obligations, but suspending funding for a particular project generally makes progress less likely rather than more, since World Bank financing may be critical to carrying out project objectives. Nevertheless, the Bank accepts the worsened outcome in the project at hand as a necessary sacrifice to maintain its reputation for enforcement. ${ }^{7}$ This trade-off looks very different from the firm's perspective. A multinational firm with investments in the borrowing country may be counting on a World Bank project to provide infrastructure that is essential to its business - roads, public utilities, harbor improvements, and so forth - and may object to suspending the funding because of noncompliance with Bank policies related to displaced populations or environmental damage. Although the firm has no direct interest in the evaluation of such a project, its lobbying may create additional incentives for the project manager to inflate the evaluation to justify the high level of disbursement and may provide political cover within the organization for doing so.

Multinational firms based in the United States are well placed to lobby the Bank to disburse funds because complying with their preferences is the path of least resistance at each stage in the chain of delegation. Lobbying typically begins with contacting a sympathetic congressional office; studies of lobbying disclosure data indicate that firms that lobby focus

6. The overall outcome variable includes three subvariables: (1) Effcacy captures the degree to which the project objectives were achieved. (2) Efficiency is a matter of "bang for the buck" (how well the money disbursed corresponds to the achievement of objectives); delays in disbursement; and attribution of the results to Bank lending. (3) Relevance is an evaluation of project objectives and their consistency with the Bank's Country Assistance Strategy for the borrowing country. For example, a project with high efficacy will receive a higher evaluation if it disburses fully without delays, but a project with low efficacy will receive a higher evaluation if it does not disburse fully.

7. This motivation may be instrumental, to save the Bank's credibility for future interactions (Stone 2002), or it may be intrinsic due to rationalbureaucratic organizational culture (Barnett and Finnemore 2004) and substantive conviction (Woods 2006). 
on Congress, and when they lobby executive agencies, generally lobby Congress as well (Baumgartner and Leech 2001). Similarly, recent formal work suggests that lobbying Congress should be more effective than lobbying executive agencies (Boehmke, Gailmard, and Patty 2013). The congressional office, likely without the member's active involvement, routinely passes on such requests to executive agencies (in this case, to the US Treasury), because that is what good constituent service requires. From the congressman's perspective, complying is costless and not complying could be costly. Treasury, for its part, likely takes a broader perspective on the costs and benefits of intervening in the operations of international financial institutions, but the cost of a bit more disbursement on one project in the World Bank's portfolio is likely to seem insignificant compared to the possibility of losing a vote on an appropriations bill, so the Treasury routinely complies with a request from a congressional office. When the request arrives at the Bank, likely in the form of an inquiry from the US executive director's office, it again seems wiser to comply than to object. The United States is the Bank's leading shareholder, and it does no one's career any good to be involved in a controversy with US officials. Lobbying is effective because the chain of delegation ensures that there is no one holding the door shut.

The mechanism of influence is more direct for Japanese firms, which have direct access to the economic ministries because they are subject to a high degree of state supervision. This is reflected in Japanese foreign aid and economic diplomacy, which consistently focuses on promoting Japanese firms' interests. Japan exercises a high degree of influence within the Bank as the second-largest shareholder in the International Bank for Reconstruction and Development (IBRD) and a leading contributor to the International Development Association (IDA). Japan worked aggressively during the 1980s to increase its voting power and influence in both the World Bank and the IMF to reflect its growing economy but was more successful in the Bank, where it was able to credibly threaten to divert development aid from IDA to its bilateral development aid program. As a result, Japanese informal control over World Bank lending in subsequent decades appears quite strong, compared to weak influence in the IMF (Lipscy 2015, supplementary materials). Japan has a weaker hand than the United States, but it plays it more systematically on behalf of its firms.

This argument proposes a mechanism of private influence that is absent from state-centered accounts of the politics of intergovernmental organizations, but the logic of the mechanism imposes scope conditions. The implication of this argument is that corporate influence should be maximized when high-level political attention is absent, so the final stages of the
Bank funding cycle are the most promising areas to identify such effects. The politics of project approval have high stakes for recipient countries and for the Bank's principals because the aggregate amount of Bank loans is large, so loan approval should be marked by geopolitical influences rather than corporate influence (Dreher, Sturm, and Vreeland 2009). In contrast, the implementation of individual projects has much lower stakes for member states. Meanwhile, firms have only weak interests in the aggregate amounts of funding committed to particular countries but have direct stakes in the disbursement of particular project loans. Corporate influence should be maximized in the project-by-project process of evaluation and disbursement, and geopolitical influences should be rare.

This draws a contrast between the informal politics of the World Bank and its sister institution, the International Monetary Fund, because IMF lending does not provide opportunities for a similar differentiation between the politics of lending and of implementation. The IMF typically has only one program active in a particular country, so there are no small-scale, differentiated projects that could be of lesser concern to country authorities. Similarly, IMF disbursements are not disaggregated in a way that would create incentives for firms to lobby on narrow grounds. Quantitative evidence about the Fund indicates that a similar pattern obtains across all stages of the project cycle, including lending decisions, design of conditionality, and enforcement of conditionality: countries important to the leading shareholders, and particularly to the United States, obtain larger loans with less stringent conditions and are subject to less rigorous enforcement. Several studies link IMF lending to UN voting patterns (see Barro and Lee 2005; Oatley and Yackee 2004; Thacker 1999) or to the exposure of US banks to particular countries (see Broz and Hawes 2006; Copelovitch 2010; Stone 2011). The design of conditionality is likewise affected by a range of variables that capture US geopolitical interests, including UN voting patterns, alliance portfolios, foreign aid, foreign trade, and US bank exposure (Dreher and Vaubel 2004; Stone 2008, 2011). ${ }^{8}$ Finally, the implementation and enforcement of conditionality depends on the same measures of US geopolitical interests (Stone 2002, 2004, 2011).

The logic of our argument implies that the most favorable conditions for corporate influence arise in the Bank, rather than in the Fund, and in project evaluation and implementation, rather than in project approval or design (table 1). In contrast to loan approval, the scope for broad foreign policy

8. The literature on the IMF is divided as to whether to interpret correlations with US bank exposure as evidence of corporate interest (Broz and Hawes 2006; Gould 2003) or of US geopolitical interest (Copelovitch 2010; Stone 2011). 
concerns to influence the process of evaluation and implementation of World Bank projects should be limited. Our empirical results find no consistent evidence of such influences.

\section{DATA}

Our primary dependent variable is Disbursement, the proportion of committed funds that are disbursed. ${ }^{9}$ Because we regard World Bank project evaluations as potentially biased, the research design requires an independent measure of project performance to determine when disbursements of funds are unjustified and evaluations are inflated. Fortunately, World Bank documentation provides a substantial amount of detail beyond the headline evaluation grade. The unit of analysis used throughout the paper is a World Bank project, and project-level information has been coded from the World Bank's Implementation Completion and Results (ICR) reports and IEG publications, which can be accessed via the Bank's website. A team of research assistants coded reports on 4,206 projects issued from October 1994 through September 2013, with project approval years ranging from 1981 to 2012. The length of the reports ranges from 20 to 200 pages. These reports represent a rich depository of information about the diversity of projects that the Bank supports, their specific objectives, and the Bank's assessment of the implementation of these objectives. Descriptive statistics for the variables used in the article can be found in table 2. The data include many more variables, some of which we have used for exploratory data analysis, and others that could be used in future research to study diverse questions regarding World Bank lending. Several recent studies have made use of meta-data drawn from ICR reports by the Bank, including official project evaluations (Denizer, Kaufmann, and Kraay 2013), but this study breaks new ground by creating an independent assessment of the underlying performance data, which allows us to draw conclusions about the Bank's evaluation procedures.

Our approach to measuring evaluation inflation is to compare the headline Outcome rating in the ICR to an index of the underlying data from the ICR on which it is based. For each project, each individual objective was scored according to the Bank evaluation team's assessment of the degree to which project goals had been achieved. Each project objective was assigned a value from 0 to 4 , where 0 represents no

9. About a fifth of the observations have disbursement rates greater than 1. Project objectives are sometimes expanded mid-course, and the official commitment amount is not always updated. This can lead to a very high disbursement proportion (maximum of 1,113). Those cases were restricted to 1 to prevent outliers from skewing the results, but the results with the unrestricted range of the variable are stronger.
Table 1. Theoretical Expectations

Lending

Evaluation/Implementation

IMF

Geopolitics

Geopolitics

World Bank

Geopolitics

Corporate influence

progress (or deterioration) and 4 indicates that the objective was completely achieved (or overachieved). ${ }^{10}$ In some cases, evaluating objectives was straightforward. For instance, one goal in an education-related project was to "increase Primary School Enrollment in Calcutta (India) from 25\% to $30 \%$," with the outcome that it was increased to $29 \%$, leading to a "performance rating" of 3 . In other cases, quantitative metrics of objective completion were unavailable, such as when the stated goal was to "spread awareness of the importance of polio vaccination in rural Punjab (Pakistan)." For such cases, the discussion of the achieved outcome was read carefully to determine success. "Marginal progress made," for instance, would be coded as 1 , whereas "significant change in awareness" would be coded as 3. The average of these objective-level ratings is our overall project-level variable, Performance.

An important limitation of the data, which will be a concern for all subsequent work that uses World Bank evaluations, is that the World Bank does not maintain consistent evaluation procedures over time. The Bank seeks to continuously improve its procedures and responds to the demands of its principals in real time. As a result, the objectives of lending programs change, the relative weights assigned to them shift, and the information collected to assess project implementation changes. This means that the most recent reports are more informative than the older ones. Fortunately, even the older reports are sufficiently rich that careful reading makes it possible to compile comparable codings for our variables, but different levels of detail lead to unavoidable heterogeneity in our measure of performance. We identify four distinct formats of ICR reports, and all of our analyses use fixed effects to control for these regimes. ${ }^{11}$

The World Bank's official assessment of project outcomes, Evaluation, is taken directly from the ICR Reports. This variable is marked in the reports as one of six categories, which

10. A " 1 " indicates that up to $1 / 3$ of the objective was achieved, " 2 " that between $1 / 3$ and $2 / 3$ of the objective was fulfilled, and " 3 " that more than $2 / 3$ of the goal was accomplished but less than $100 \%$.

11. The most recent report types are associated with lower Evaluation scores, higher Performance scores, and higher Disbursement ratios, which is consistent with the Bank's objectives in tightening up the evaluation procedure to strengthen performance incentives. Section 1 of the appendix discusses ICR reports and the coding of variables in more detail. 
108 / Corporate Influence in World Bank Lending Rabia Malik and Randall W. Stone

Table 2. Descriptive Statistics

\begin{tabular}{|c|c|c|c|c|c|}
\hline Statistic & Mean & Median & SD & Min & Max \\
\hline Disbursement proportion & .895 & .993 & .188 & .000 & 1.000 \\
\hline Evaluation & 4.436 & 5 & 1.141 & 1 & 6 \\
\hline Performance & 3.019 & 3.000 & .806 & .000 & 4.000 \\
\hline MNC contractor & .277 & 0 & .448 & 0 & 1 \\
\hline US MNC & .106 & 0 & .308 & 0 & 1 \\
\hline US Fortune 500 & .444 & .047 & .860 & .000 & 4.261 \\
\hline MNC management contractor & .021 & 0 & .142 & 0 & 1 \\
\hline US MNC management & .008 & 0 & .090 & 0 & 1 \\
\hline Polity $_{t-1}$ & 3.167 & 6 & 5.875 & -10 & 10 \\
\hline $\log \left(\right.$ Population $\left._{t-1}\right)$ & 17.040 & 16.884 & 1.968 & 10.701 & 21.024 \\
\hline $\log \left(\right.$ GDP per capita $\left.{ }_{t-1}\right)$ & 7.950 & 7.965 & .958 & 5.276 & 10.273 \\
\hline Control of corruption & 2.414 & 2.333 & .810 & .000 & 5.000 \\
\hline Report type 4 & .381 & 0 & .486 & 0 & 1 \\
\hline Report type 3 & .199 & 0 & .399 & 0 & 1 \\
\hline Report type 2 & .092 & 0 & .289 & 0 & 1 \\
\hline Report type 1 & .328 & 0 & .469 & 0 & 1 \\
\hline IBRD & .326 & 0 & .469 & 0 & 1 \\
\hline IDA & .528 & 0 & .499 & 0 & 1 \\
\hline Approval year & 1998 & 1998 & 6.144 & 1981 & 2012 \\
\hline Report year & 2003 & 2004 & 5.433 & 1990 & 2013 \\
\hline Project size per capita & 5.407 & 1.987 & 11.690 & .004 & 193.688 \\
\hline
\end{tabular}

Note. IBRD = International Bank for Reconstruction and Development; IDA = International Development Association; MNC = multinational corporation.

we convert to a 1 to 6 ordinal scale. ${ }^{12}$ Figure 1 depicts the raw relationship between Performance and Evaluation. The figure plots the density of Performance for each level of Evaluation and indicates that there is considerable variation in project performance that is not captured by evaluations.

Our main independent variable of interest, involvement of multinational corporations (MNCs), is measured in two ways. Our first measure relies on the World Bank's Contract Awards Database. MNC Contractor is a project-level dummy variable indicating whether a Fortune Global 500 firm or one of its affiliates was directly involved in a World Bank project. The World Bank provides information on contracts signed after July $1,2000 .{ }^{13}$ This data set includes 2,387 projects; ICR reports are available for 1,790 of these projects. Using the Fortune Global 500 list and data on mergers and acquisitions from SDC Platinum, we matched all World Bank contractors that were either Fortune Global 500 firms or had been acquired by or had merged with those firms. Specifically,

12. The six categories with numerical ranking are highly satisfactory (6), satisfactory (5), moderately satisfactory (4), moderately unsatisfactory (3), unsatisfactory (2), and highly unsatisfactory (1).

13. The World Bank's Contract Awards data can be accessed at http:// go.worldbank.org/GM7GBOVGS0. we focused on the subset of these that were headquartered in the United States, France, Germany, Japan, and the United Kingdom. For any project that had such a contractor, $M N C$ Contractor takes on a value of 1 . In the sample of projects used for the final regressions presented in this paper, almost $28 \%$ involved at least one MNC contractor. We also construct variables for MNC Contractors headquartered in the United States (US MNC), Germany, Japan, France, and the United Kingdom, and compare the results.

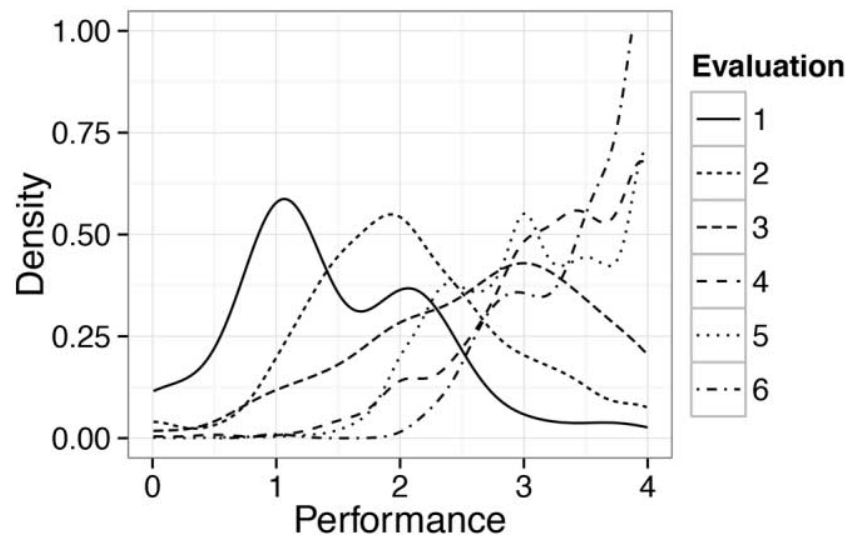

Figure 1. Performance and evaluation 
A second measure is a country-level measure of foreign direct investment by Fortune Global 500 firms. We are theoretically interested in strategic investments by major multinational firms rather than in flows of FDI, per se, and we are interested in the national origins of these firms. Consequently, we extracted firm-level data on mergers and acquisitions activity from SDC Platinum, which we merged with data from the Fortune Global 500 list, expanded to include all firms that fell into the top 500 during any year in the last two decades. Because of extensive missing values for the value of transactions, we use a count of transactions to construct our index. For each of the five countries listed above, we calculate the percentage of total Fortune Global 500 mergers and acquisitions in each recipient country in the data set in each year and use a five-year moving average of this variable in the regressions. See table 2 for summary statistics.

MNC Contractor is a more direct measure of firms' interest in World Bank projects than Fortune 500 Investment because it identifies a particular firm that is involved in a particular project. Consequently, it allows us to draw stronger conclusions about the motivations of the firms involved. However, this specificity also limits the range of motivations for foreign investors to exert influence to the direct pecuniary interest of project contractors. Fortune 500 firms that invest in developing countries may develop vested interests in World Bank projects for a wide range of reasons that do not involve performing contract work. Thus, the two measures of MNC interest are complementary. MNC Contractor varies at the project level, and Fortune 500 Investment varies at the countryyear level. The two are not highly correlated (the correlation between US MNC and US Investment is $r=0.10$ ), so they allow independent tests of our hypotheses. For correlations between the main variables of interest, see figure A5 in the appendix (appendix and figs. A1-A8 available online).

\section{EMPIRICAL ANALYSIS}

We first estimate effects of MNC Contractors on disbursements and then delve deeper into the proposed mechanisms. First, we disaggregate MNC contractors by country of origin, allowing us to assess the importance of access to decision makers from particular countries. Second, we zero in on the particular contractors that are most likely to have incentives to influence Bank policy, which are contractors with management functions. Third, we analyze models of evaluation to detect whether evaluations are biased on projects that involve MNC contractors. Fourth, we use performance as our dependent variable to evaluate the alternative explanation that MNC contractors improve the outcomes of Bank projects. Fifth, we turn to our alternative measure of MNC interest, Fortune 500 Investment, to probe the robustness of our find- ings and explore whether lobbying influence extends to firms that are not involved as contractors but may benefit from Bank projects in other ways. Throughout our analysis, we estimate OLS regressions with World Bank projects as the unit of analysis, using country, year, and report-type fixed effects.

\section{MNC contractors}

Firms are hired on contracts by the recipient country, which receives loan disbursements from the Bank, so firms that seek to collect payment for their services have incentives to lobby for disbursement to the recipient country. On the other hand, controlling disbursements is the Bank's primary tool to incentivize compliance by borrowing countries, so undermining this incentive scheme has far-reaching consequences. The expectation is that MNC Contractor will increase disbursement, while controlling for project performance. Controlling for performance allows us to interpret positive effects as disbursements that were not justified by the implementation of program conditions or accomplishment of project objectives. To motivate the analysis that follows, table 3 divides the projects in our data along two dimensions, performance and involvement of MNC contractors, and compares the average disbursement rates in each subset. Projects with MNC contractors have higher disbursement, both among high- and low-performing projects; these differences are statistically significant.

Table 4 presents regression results that allow us to investigate this pattern more rigorously. MNC Contractor is significantly associated with higher disbursement rates, controlling for project performance. Including both country and year fixed effects rules out a number of alternative explanations for our results based on spurious correlations and omitted variables. The estimated marginal effect of an MNC contractor is a $2.7 \%$ increase in the disbursement ratio-a modest but significant effect that affects the bottom lines of the firms involved. Project evaluations have a significant effect on disbursements as well: increasing the evaluation by one grade, for example, from moderately unsatisfactory to moderately satisfactory, increases the disbursement ratio by $4.7 \%$. It is striking that the estimated effect of an MNC contractor is more than half as great as a higher evaluation. The effects of performance, however, are insignificant when we control for

Table 3. MNC Involvement, Performance, and Average Disbursement

\begin{tabular}{lccc} 
Performance & Any MNC & No MNC & $p$-Value of Diff. \\
\hline High & .95 & .92 & .020 \\
Low & .89 & .86 & .026 \\
\hline
\end{tabular}


Table 4. Project Disbursement and MNC Contractors

\begin{tabular}{|c|c|c|c|c|c|c|}
\hline & $\begin{array}{c}\text { Any MNC } \\
\text { (1) }\end{array}$ & $\begin{array}{l}\text { US } \\
(2)\end{array}$ & $\begin{array}{c}\text { France } \\
\text { (3) }\end{array}$ & $\begin{array}{c}\text { Germany } \\
(4)\end{array}$ & $\begin{array}{c}\text { Japan } \\
(5)\end{array}$ & $\begin{array}{l}\text { UK } \\
(6)\end{array}$ \\
\hline Performance & $\begin{array}{c}.012 \\
(.008)\end{array}$ & $\begin{array}{c}.011 \\
(.008)\end{array}$ & $\begin{array}{c}.011 \\
(.008)\end{array}$ & $\begin{array}{c}.011 \\
(.008)\end{array}$ & $\begin{array}{c}.011 \\
(.008)\end{array}$ & $\begin{array}{c}.011 \\
(.008)\end{array}$ \\
\hline Evaluation & $\begin{array}{l}.047^{\star \star \star} \\
(.006)\end{array}$ & $\begin{array}{l}.047^{\star * *} \\
(.006)\end{array}$ & $\begin{array}{l}.047^{\star * *} \\
(.006)\end{array}$ & $\begin{array}{l}.047^{\star \star *} \\
(.006)\end{array}$ & $\begin{array}{l}.047^{\star * *} \\
(.006)\end{array}$ & $\begin{array}{l}.047^{\star * *} \\
(.006)\end{array}$ \\
\hline Any MNC & $\begin{array}{l}.027^{\star \star} \\
(.011)\end{array}$ & & & & & \\
\hline US MNC & & $\begin{array}{c}.026^{*} \\
(.015)\end{array}$ & & & & \\
\hline France $\mathrm{MNC}$ & & & $\begin{array}{c}.007 \\
(.017)\end{array}$ & & & \\
\hline Germany MNC & & & & $\begin{array}{r}-.023 \\
(.029)\end{array}$ & & \\
\hline Japan MNC & & & & & $\begin{array}{c}.033^{*} \\
(.017)\end{array}$ & \\
\hline UK MNC & & & & & & $\begin{array}{r}-.015 \\
(.052)\end{array}$ \\
\hline Proj. size pc & $\begin{array}{r}-.0001 \\
(.001)\end{array}$ & $\begin{array}{c}-.00002 \\
(.001)\end{array}$ & $\begin{array}{l}.00001 \\
(.001)\end{array}$ & $\begin{array}{c}.0001 \\
(.001)\end{array}$ & $\begin{array}{c}.0001 \\
(.001)\end{array}$ & $\begin{array}{l}.0001 \\
(.001)\end{array}$ \\
\hline Polity $_{t-1}$ & $\begin{array}{c}.004 \\
(.004)\end{array}$ & $\begin{array}{c}.004 \\
(.004)\end{array}$ & $\begin{array}{c}.004 \\
(.004)\end{array}$ & $\begin{array}{c}.004 \\
(.004)\end{array}$ & $\begin{array}{c}.004 \\
(.004)\end{array}$ & $\begin{array}{c}.004 \\
(.004)\end{array}$ \\
\hline Corruption control & $\begin{array}{c}.013 \\
(.012)\end{array}$ & $\begin{array}{c}.014 \\
(.012)\end{array}$ & $\begin{array}{c}.014 \\
(.012)\end{array}$ & $\begin{array}{c}.015 \\
(.012)\end{array}$ & $\begin{array}{c}.013 \\
(.012)\end{array}$ & $\begin{array}{c}.014 \\
(.012)\end{array}$ \\
\hline $\log (\mathrm{GDP} p c)_{t-1}$ & $\begin{array}{r}-.015 \\
(.062)\end{array}$ & $\begin{array}{r}-.015 \\
(.062)\end{array}$ & $\begin{array}{r}-.016 \\
(.062)\end{array}$ & $\begin{array}{r}-.018 \\
(.062)\end{array}$ & $\begin{array}{r}-.021 \\
(.062)\end{array}$ & $\begin{array}{r}-.016 \\
(.062)\end{array}$ \\
\hline $\log (\text { Population })_{t-1}$ & $\begin{array}{c}-.081 \\
(.180)\end{array}$ & $\begin{array}{r}-.063 \\
(.180)\end{array}$ & $\begin{array}{r}-.063 \\
(.181)\end{array}$ & $\begin{array}{r}-.062 \\
(.180)\end{array}$ & $\begin{array}{c}-.084 \\
(.181)\end{array}$ & $\begin{array}{r}-.059 \\
(.181)\end{array}$ \\
\hline IBRD & $\begin{array}{c}-.008 \\
(.014)\end{array}$ & $\begin{array}{r}-.007 \\
(.014)\end{array}$ & $\begin{array}{r}-.006 \\
(.014)\end{array}$ & $\begin{array}{r}-.005 \\
(.014)\end{array}$ & $\begin{array}{c}-.006 \\
(.014)\end{array}$ & $\begin{array}{r}-.006 \\
(.014)\end{array}$ \\
\hline Report FE & $\checkmark$ & $\checkmark$ & $\checkmark$ & $\checkmark$ & $\checkmark$ & $\checkmark$ \\
\hline Country FE & $\checkmark$ & $\checkmark$ & $\checkmark$ & $\checkmark$ & $\checkmark$ & $\checkmark$ \\
\hline Year FE & $\checkmark$ & $\checkmark$ & $\checkmark$ & $\checkmark$ & $\checkmark$ & $\checkmark$ \\
\hline$N$ & 1,167 & 1,167 & 1,167 & 1,167 & 1,167 & 1,167 \\
\hline Adj. $R^{2}$ & .970 & .970 & .970 & .970 & .970 & .970 \\
\hline
\end{tabular}

Note. IBRD = International Bank for Reconstruction and Development; MNC = multinational corporation.

${ }^{*} p<.1$.

$* * p<.05$.

${ }^{* * *} p<.01$.

evaluations; it is the evaluations that are important for setting incentives, rather than the underlying performance data. Other control variables are significant in other specifications, but lose significance when we add year, country, and reporttype fixed effects.

The second stage of our analysis disaggregates our results by the firms' countries of origin (table 4, cols. 2-6). This allows us to explore whether the mechanism driving our correlations is political influence, in which case firms from various countries might be expected to be treated differently, or whether, instead, the results are driven by some other economic, technical or bureaucratic factor that is associated with the contract bidding process. The results suggest a political interpretation. As expected, the firms from the countries with the most influence in the World Bank, the United States and Japan, are associated with increased disbursements, while those from France, Germany, and the United Kingdom are not. The results are marginally significant $(p=.09$ for US firms, $p=.06$ for Japanese firms) but substantively indistinguishable from the effect for all MNCs.

We can dial up the power of our tests by using the fact that the World Bank identifies each contract's type, which tells us 
Table 5. Project Disbursement and MNC Management Contractors

\begin{tabular}{ccccccc}
\hline & Any MNC & US & France & Germany & Japan & UK \\
\hline \multirow{2}{*}{ Coefficient on MNC variable } & $.072^{* *}$ & $.101^{* *}$ & .048 & .026 & .076 & .090 \\
& $(.030)$ & $(.045)$ & $(.052)$ & $(.075)$ & $(.085)$ & $(.122)$ \\
\hline
\end{tabular}

Note. Coefficients and standard errors in parentheses. All models include country, year and report type fixed effects. The specifications are the same as in table 4. Full results are in table A5.

${ }^{*} p<.1$.

${ }^{* *} p<.05$.

${ }^{* * *} p<.01$.

which contractors are most likely to bear some residual responsibility for project completion. The World Bank's Contracts Database assigns a procurement type to each contract, and we aggregate the types of contract involving residual responsibilities into a management category. Our expectation is that the effects will be stronger, because firms have greater financial interest in the disbursement schedule when they are engaged as general contractors, while they may expect to be fully paid regardless of the outcome of the project when their responsibilities are more limited.

Table 5 summarizes the results. Each column contains the main coefficient of interest from a separate regression, as indicated by the column heading. The specifications are the same as in the previous table, and complete results can be found in the appendix (table A5; tables A1-A29 available online). Contractors with management responsibilities are associated with disbursement rates that are $7.2 \%$ above the average, a statistically significant effect that is two and a half times the average effect of MNC contractors. ${ }^{14}$ The stronger effect for management contractors suggests that the mechanism driving the result is likely to be the influence exerted by the firm. When we disaggregate the results by country of origin, the effect for US firms is estimated to be an even greater $10.1 \%$ increase in disbursement. The effects for firms from other countries are insignificant. The diverse treatment of firms from different countries suggests a prima facie case for a political interpretation.

To probe more deeply into the proposed mechanism, we now consider the Bank's evaluations of individual projects as the outcome of interest. If it is the case that pressure from firms explains the higher than expected disbursement rates, then we also expect to see more evaluation inflation in those instances, because higher evaluations are needed to justify

14. The appendix contains robustness checks to deal with the fact that Disbursement Proportion is left-skewed (see fig. A3). Tables A12 and A13 present results using (simple) bootstrapped and country-clustered bootstrapped errors, and table A14 presents results of fractional logit models. the higher disbursements. We focus on contractors with management responsibilities; the results for all contractors are somewhat weaker. ${ }^{15}$ The main results are summarized in table 6. The control variables are the same as in the Disbursement models above; full results are in table A6.

One point on the Performance scale predicts more than two-thirds of a point on the Evaluation scale. Because we control for performance, we can interpret the other coefficients as effects on evaluation inflation; that is, they capture the degree to which a covariate is associated with excessively positive evaluations that are unjustified by the underlying data. MNC Management Contractor has a positive and significant coefficient in the first model, indicating that evaluation inflation is highest when an MNC is involved as a contractor with management responsibilities. ${ }^{16}$ This result is consistent with our interpretation of the disbursement models, that multinational firms collude with Bank staff to frustrate project monitoring. Results disaggregated by countries of origin also support this interpretation. The substantive effect is stronger but less precisely estimated for US firms $(p=.06)$ and is stronger and significant for Japanese firms. French and German firms are not significantly associated with inflated evaluations, and the significant negative coefficient for UK firms rejects the hypothesis of any positive association. The pattern is consistent with our findings about disbursement: leading MNCs are associated with excess disbursements and inflated evaluations, but the effect appears to be limited to firms from the countries that are the Bank's leading shareholders.

15. Using MNC Contractor rather than Management Contractor in models of Evaluation leads the main variable to lose significance at conventional levels when including both country and year fixed effects. However, the results are significant and comparable when including either country or year fixed effects. All three sets of results can be found in tables A17-A19.

16. Tables A20 and A21 replicate these results using ordered probit models without fixed effects. The ordered probit models with fixed effects do not converge. 
112 / Corporate Influence in World Bank Lending Rabia Malik and Randall W. Stone

Table 6. Project Evaluation and Management MNC Contractors

\begin{tabular}{lcccccc}
\hline & Any MNC & US & France & Germany & Japan & UK \\
\hline Coefficient on MNC variable & $.358^{* *}$ & $.448^{*}$ & .325 & .296 & $.907^{* *}$ & $-1.716^{* * *}$ \\
& $(.156)$ & $(.237)$ & $(.282)$ & $(.342)$ & $(.459)$ & $(.662)$ \\
\hline
\end{tabular}

Note. Each coefficient represents a different regression. All models include country, year, and report fixed effects. MNC = multinational corporation. The specification for each regression is the same as the models presented in table 4, with the following exception: Evaluation is now the dependent variable. Full results can be found in table A6.

${ }^{*} p<.1$.

${ }^{* *} p<.05$.

${ }^{* * *} p<.01$.

We now turn to models that use Performance as the dependent variable in order to probe an alternative explanation for our results, which is that MNC contractors-especially management contractors - are associated with greater disbursements and higher evaluations because they improve project outcomes. Summarized results are reported in table 7 , where each column again presents the main coefficient of interest from a separate regression; the specifications are the same as those presented in table 6, and full results can be found in table A7. Performance is the objective-by-objective index of project completion that we compiled from ICRs. If we found a positive association between Performance and MNC Contractor, this would undermine our interpretation that disbursements and evaluations are driven by political influence. However, the coefficient for MNC Management Contractor is negative and marginally significant $(p=.05)$, which rejects the hypothesis that the involvement of MNCs promotes the implementation of World Bank projects. This result is consistent when using all MNC Contractors as well (see table A22). When we disaggregate by firm country of origin, the corresponding coefficients are negative but insignificant for US and French firms, negative and significant for Japanese and British firms, and insignificant for German firms. This indicates that most of the downward pull on performance exerted by MNCs comes from Japanese and British firms, but none of the subsamples betrayed any evidence that MNCs are associated with stronger performance.

\section{Fortune $\mathbf{5 0 0}$ investment}

We now explore the robustness and substantive scope of our findings by employing a set of alternative independent variables to measure MNC interests derived from merger and acquisition (M\&A) activity by leading firms. The hypothesis behind these measures is that firms that are not contractors but that have investments in the borrowing country may nevertheless benefit from Bank projects. Consequently, MNCs may lobby for disbursement in order to increase the odds of completion of projects that are beneficial to their businesses, irrespective of human rights or environmental considerations that might otherwise derail them. In order to capture this incentive, we calculate the shares of M\&A investments from each of our five countries of origin that go to particular countries over a moving five-year period. For example, US Fortune 500 is calculated as the number of mergers and acquisitions by US Fortune Global 500 firms in the borrowing country divided by the total number of foreign M\&As by US Fortune Global 500 firms.

The weakness of this measure, compared to MNC Contractor, is that we do not know whether a particular firm has an interest in a particular project. Thus, we employ an in-

Table 7. Project Performance and Management MNC Contractors

\begin{tabular}{lcccccc}
\hline & Any MNC & US & France & Germany & Japan & UK \\
\hline Coefficient on MNC manag. & $-.272^{*}$ & -.011 & -.344 & .027 & $-1.103^{* * *}$ & $-1.552^{* * *}$ \\
& $(.139)$ & $(.212)$ & $(.252)$ & $(.305)$ & $(.408)$ & $(.590)$ \\
\hline
\end{tabular}

Note. Each coefficient represents a different regression. The specification for each regression is the same as the models presented in table 4, with the following exception: Performance is now the dependent variable. Full results can be found in the table A7. All models include country, year, and report fixed effects.

${ }^{*} p<.1$.

${ }^{* *} p<.05$.

${ }^{* * *} p<.01$. 
Table 8. Disbursement and Fortune 500 Investment

\begin{tabular}{lccccr}
\hline & US & France & Germany & Japan & UK \\
\hline \multicolumn{1}{l}{ Investment } & & & & & \\
& .026 & $.028^{\star *}$ & .015 & $-.034^{*}$ & -.002 \\
Investment $\times$ project size & $(.016)$ & $(.013)$ & $(.016)$ & $(.020)$ & $(.014)$ \\
& $.005^{*}$ & .002 & -.003 & $.009^{* *}$ & .004 \\
& $(.002)$ & $(.001)$ & $(.002)$ & $(.004)$ & $(.003)$ \\
\hline
\end{tabular}

Note. Each column presents the main coefficients of interest from a separate regression, and each column heading indicates the country whose Fortune 500 investment is represented. The other variables are the same as those used in table 4 and full results are in table A8. All models include country, year, and report-type fixed effects.

${ }^{*} p<.1$.

${ }^{* *} p<.05$.

$* * * p<.01$.

teraction term that is designed to screen out investors that are less likely to have interests in particular projects. We expect large projects to be of interest to more firms and MNC interest to be attenuated on average in large countries. Consequently, the specifications include interaction terms between our measures of investment by national firms and project size per capita, and the interaction effects are expected to be positive.

Table 8 presents summarized results from five models of disbursement, using investment proportions for the United States, France, Germany, Japan, and the United Kingdom, respectively, to measure the intensity of firm interests. As before, each column presents the main variables of interest from a separate regression, and the investment country of origin is indicated by the column headings. The specifications are the same as those in the earlier disbursement models, shown in table 4; full results can be found in table A8. As table 8 indicates, investment by US multinational firms has an effect that is significant and substantively strong. Specifically, the effect of the presence of multinational firms that is one standard deviation above the mean on a project of average size is to increase disbursement by $7.1 \%$. This is larger than the effect of increasing performance by a standard deviation. ${ }^{17}$ Figure 2 plots the composite coefficient for US Investment, taking into account the interaction with project size. ${ }^{18}$

The $x$-axis covers most of the range of project size per capita in the data (only 42 observations are larger than $\$ 50$ per capita.) The shaded area represents the $95 \%$ confidence interval. Projects larger than $\$ 1.30$ per capita are associated with a significant effect, which includes about two-thirds of

17. The results are robust to including sectoral fixed effects (table A23).

18. Table A16 presents similar results using a standardized version of Project size per capita. the projects in our data set. ${ }^{19}$ Holding other variables at their means, a one-unit increase (i.e., 1 percentage point) in US investment is estimated to increase disbursement by $10.1 \%$ for a $\$ 15$ per capita project.

The fact that we find similar results using different samples and different measures of MNC involvement is reassuring. Indeed, the low correlation between US Investment and US MNC Contractor $(r=0.10)$ reflects the fact that the two variables measure different concepts - the presence of major US multinational firms in a particular country, as opposed to the involvement of such a firm as a contractor on a particular World Bank project. Nevertheless, the results suggest that each captures an important dimension of MNC influence over the World Bank. Furthermore, the fact that all of these results are robust to including country and year fixed effects rules out alternative interpretations of our results based on fixed country-specific characteristics or contemporaneous shocks.

Consider how these estimated effects relate to a substantive example drawn from the data. The Yacyretá Hydroelectric Project II was active in Argentina from 1992 to 2000 with a total project commitment of $\$ 300$ million. The Yacyretá Dam is a joint venture between Argentina and Paraguay negotiated in 1973, and both the World Bank and the InterAmerican Development Bank provided funds for parts of the project at various points. This particular World Bank project was launched in 1992, and its focus was constructing the dam

19. Similar figures for French and Japanese Fortune Global 500 MNC investment are in the appendix (figs. A6, A7). We do not emphasize them because they are less impressive. The composite effect of French Investment is much smaller, peaking at half the substantive size of the corresponding effect of US Investment. Japanese Investment has a larger substantive effect but only gains significance for projects larger than about $\$ 22$ per capita, which constitute fewer than $5 \%$ of the observations in our data. 
114 / Corporate Influence in World Bank Lending Rabia Malik and Randall W. Stone

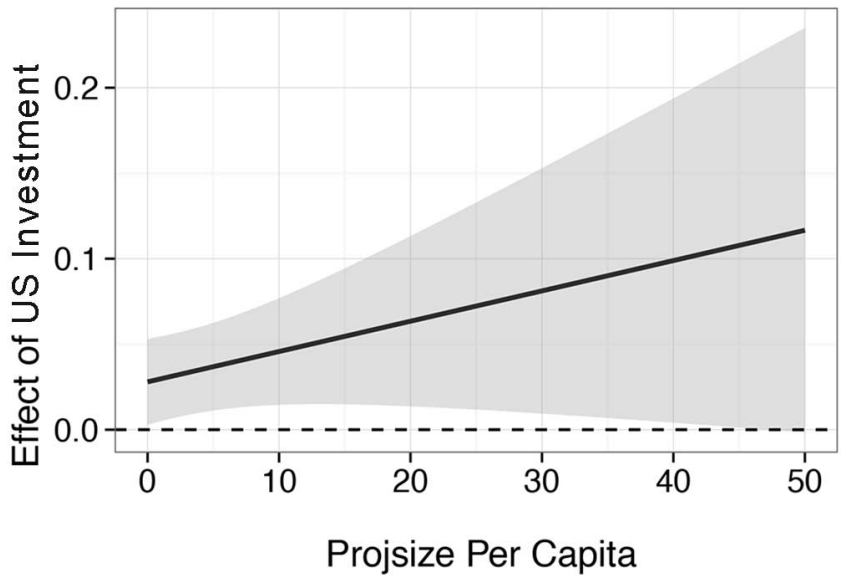

Figure 2. Marginal effect of US investment on disbursement

and financing programs for infrastructure relocation, population resettlement and environmental impact mitigation. The Bank evaluated the project's outcome as "unsatisfactory," yet the financing for the project was fully disbursed.

The project was shadowed by ecological and human-rights protests from the outset. The original construction plan called for a height of 83 meters above sea level, but construction was stopped at 76 meters to avoid displacing an additional 80,000 inhabitants. As a result, the facility achieved only $60 \%$ of the originally planned generating capacity of $3200 \mathrm{MW}$. The project was plagued by cost overruns and allegations of corruption, which led former Argentine President Carlos Menem to label it a "monument to corruption." Officials of the Entidad Binacional Yacyretá (EBY), which administers the facility, were convicted of embezzlement and insider trading, and the EBY was charged with violations of human rights by the Inter-American Court of Human Rights. The ICR report evaluated the project as unsatisfactory because it failed to provide efficient supply of energy, to ameliorate environmental and social impacts, or to reach the targeted level of net present value and economic rate of return. The only target that was fully achieved was increasing private capital participation in EBY.

The dam's conception, planning, design, and construction were managed by MWH Global, which is a US Fortune 500 corporation. MWH involvement is not discussed in the ICR report itself (and the project predates the available data from the Contract Awards Database), but the company's website provides a summary of the Yacyretá Hydroelectric Project that outlines its role. This appears to be a case in which a project's performance did not justify its high rate of disbursement, but a prominent US multinational corporation had a stake in the funds being fully disbursed. Our results estimate that US MNCs that take on management contracts increase disbursement by $10.1 \%$. Furthermore, our estimates attribute $12.8 \%$ of the disbursement for this project to the influence of US multinational investment.

It is instructive to further investigate MWH Global in its role as a contractor on World Bank projects. There are 13 such projects in our data set beginning in 2000, as summarized in table 9. MWH served as a general contractor, with a share of the contract for each project ranging from $\$ 300,000$ to $\$ 8.9$ million, on a portfolio of projects totaling $\$ 1.05$ billion. In sum, 11 of these 13 projects were fully disbursed or expanded, for an average disbursement rate of $102 \%$. However, the evaluation of these projects was unimpressive, averaging a moderately unsatisfactory 3.9 (on a 6-point scale). Even the project with the worst performance, a water treatment project in Lebanon that received the worst possible evaluation, was fully disbursed. MWH earned a total of $\$ 31$ million in contracting fees from the World Bank for supervising this series of unimpressive projects.

It is in the nature of lobbying that it is difficult to detect, so we would be unlikely to find direct evidence that $\mathrm{MWH}$ benefited from US government support in its interactions with the World Bank. However, reforms enacted in the 1990s ensured that lobbying leaves some traces. The Lobbying Disclosure Act of 1995, as amended, requires lobbyists to register with the Federal government and to disclose their client lists. The Lobbying Disclosure Act Database indicates that MWH was a registered client of the Livingston Group from 2006 through 2008 and paid retainers of $\$ 170,000 .^{20}$ The Livingston Group is a leading Republican lobbying firm headed by Robert Livingston, a former House Appropriations Chairman, ${ }^{21}$ who has been quoted as saying, "There's unlimited business out there for us." ${ }^{\text {22 }}$ Its client list includes the countries of Libya, Egypt, and Azerbaijan, as well as numerous US Fortune 500 firms. Congressman Livingston's personal disclosures indicate that he contributed to numerous Republican House and Senate campaigns, which might be considered to be investments in his influence business. There is no way to know whether the group specifically lobbied on behalf of MWH contracts with the World Bank, but it is evident that MWH regarded lobbying as part of its business strategy.

\section{DISCRIMINATION AMONG ALTERNATIVE THEORIES}

We conduct two additional tests in order to further narrow the possible interpretations of our findings. First, we con-

20. Lobbying Disclosure Act Database, United States Senate. soprweb .senate.gov/index.cfm? event $=$ selectfields.

21. Livingston resigned his House seat in 1999 after being selected as Speaker elect because of concerns that his extramarital affair would complicate the effort to impeach President Clinton.

22. Jeffrey H. Birnbaum, "The Road to Riches Is Called K Street," The Washington Post, June 22, 2005. 


\begin{tabular}{|c|c|c|c|c|c|c|c|}
\hline Country & Title & Start & End & Comm. & Disb.\% & Eval. & $\mathrm{MWH}$ \\
\hline Cambodia & Road rehabilitation & 1999 & 2006 & 32.3 & $107 \%$ & 4 & 1.3 \\
\hline Vietnam & Mekong trans. and flood protection & 2000 & 2011 & 87.9 & $100 \%$ & 4 & .3 \\
\hline China & Sichuan urban environment & 1999 & 2007 & 102.0 & $44 \%$ & 4 & 4.1 \\
\hline China & Liao river basin & 2001 & 2008 & 100.0 & $92 \%$ & 5 & 2.3 \\
\hline China & Tongbai pumped storage & 1999 & 2007 & 197.5 & $100 \%$ & 5 & .2 \\
\hline Yemen & Urban water supply and sanitation & 2002 & 2010 & 84.7 & $104 \%$ & 4 & 8.9 \\
\hline China & Tai basin urban environment & 2004 & 2010 & 57.5 & $100 \%$ & 3 & .9 \\
\hline Brazil & Fortaleza metropolitan transport & 2001 & 2010 & 22.4 & $155 \%$ & 4 & 2.0 \\
\hline Laos & Agricultural development & 2001 & 2008 & 13.1 & $123 \%$ & 4 & 3.5 \\
\hline China & Zhejiang urban environment & 2004 & 2011 & 133.0 & $100 \%$ & 5 & 3.8 \\
\hline Bulgaria & Wetlands restoration & 2002 & 2008 & 7.5 & $100 \%$ & 5 & .8 \\
\hline Lebanon & Ba'albeck water and wastewater & 2002 & 2012 & 43.5 & $101 \%$ & 0 & 6 \\
\hline China & Hunan urban development & 2004 & 2012 & 172.0 & $100 \%$ & 4 & 2.5 \\
\hline
\end{tabular}

Note. "Comm." is the original Commitment amount in million USD. MWH is the million USD amount of the MWH contract.

duct a simple placebo test to isolate the effects of strategic investment decisions by major multinationals from the background conditions that promote FDI. If some unmeasured variable that is associated both with FDI and with favorable outcomes on World Bank projects accounts for our results, it should be possible to replicate our findings by substituting aggregate FDI for our measures of MNC involvement. We do this using data for FDI flows and stocks and cannot reject the null hypothesis of no effects. Results can be found in the appendix (columns 1 and 4, respectively, in table A24). In addition, we replicate our disbursement results using each measure of MNC involvement and find that the main results continue to hold when we add FDI flows and stocks as additional controls (see table A24 for full results). This indicates that it is the involvement of major MNCs per se, and not simply FDI, that produces the effects we find.

Second, we seek to distinguish the mechanism of corporate influence from the mechanism of geopolitics. It could be that the presence of US multinationals serves as a proxy for broader US interests in recipient countries, and it might be these interests rather than those of business that are finding expression in World Bank lending (Gilpin 1975; Krasner 1978). If this is the case, other measures of US geopolitical interests that are associated with IMF lending behavior should have similar effects in the case of the Bank.

\section{Geopolitical interests}

Table 10 summarizes the estimated effects on disbursements of five measures of US geopolitical interests. Each entry represents the main coefficient from a separate regression, and the geopolitical variables are indicated by the column head- ings. Full results are in the appendix (tables A10, A11). The first row of models in table 10 includes only report-type fixed effects, and the second row includes report, country, and year fixed effects. The five geopolitical variables have been found to be relevant in the literature, and are added one-at-atime to our baseline disbursement model.

The Executive Director and UNSC Membership dummy variables indicate whether the project-recipient country held a seat on the World Bank Executive Board or on the United Nations Security Council, respectively, during the project implementation period. The other three variables are specific measures of US geopolitical interest in the project recipient. We consider whether countries that receive higher levels of (lagged) US aid are also more likely to receive larger disbursement percentages on their projects from the Bank. We also measure US interest in terms of the (lagged) UN Voting affinity S-score between the United States and each projectrecipient country. Important UN Votes calculates the S-score based only on those votes that the US State Department has identified in its annual report to Congress to be important to US foreign policy, whereas All UN Votes includes all votes in the United Nations General Assembly.

The results provide little support for the influence of geopolitical variables. ${ }^{23}$ None of the variables has a significant coefficient in the specifications without country and year fixed effects. Only one of the 10 coefficients is significant, that of All UN Votes in the specification with country and year fixed

23. Also see Kilby $(2009,2013)$. Kilby's work is also discussed in section 3.1 of the appendix where we replicate our main models, controlling for his US Friend variable. 
Table 10. Disbursement and Geopolitical Interests

\begin{tabular}{|c|c|c|c|c|c|}
\hline & US $\operatorname{Aid}_{t-1}$ & All UN Votes Vol $_{t-1}$ & Imp. UN Votes ${ }_{t-1}$ & UNSC & $\mathrm{ED}$ \\
\hline \multirow[t]{2}{*}{ Geopolitical variable } & -.024 & .023 & .006 & .014 & .013 \\
\hline & $(.083)$ & $(.024)$ & $(.014)$ & $(.012)$ & $(.015)$ \\
\hline Fixed effects & $x$ & $x$ & $x$ & $x$ & $x$ \\
\hline \multirow[t]{2}{*}{ Geopolitical variable } & .075 & $.120^{\star *}$ & -.001 & -.003 & -.001 \\
\hline & $(.096)$ & $(.049)$ & $(.019)$ & $(.013)$ & $(.017)$ \\
\hline Fixed effects & $\checkmark$ & $\checkmark$ & $\checkmark$ & $\checkmark$ & $\checkmark$ \\
\hline
\end{tabular}

\footnotetext{
Note. All 10 coefficients shown here represent the main coefficient of interest from a separate regression, where the column heading indicates the geopolitical variable each model focuses on. The other variables are the same as those used in table 4, and full results can be seen in tables A10 and A11, respectively. Finally, all models include report type fixed effects, while "Fixed effects" in the latter set of results refers to country and year fixed effects.

${ }^{*} p<.1$.

${ }^{* *} p<.05$.

${ }^{* * *} p<.01$.
}

effects. In addition, the result is not robust, ${ }^{24}$ and $\mathrm{UN}$ voting is not associated with inflated evaluations. ${ }^{25}$ When we include all of the geopolitical factors and US Fortune 500 in the same equation (table A26), the effect of US Fortune 500 investment is consistent, but none of the geopolitical variables are significant.

We conclude from this exercise that the range of interpretations of our results has considerably narrowed. Measures of US interests other than multinational investments do not seem to explain patterns of World Bank lending, so the effect of multinational presence is unlikely to be a proxy for geopolitical interests. Rather, it represents the effects of political activity that firms pursue on their own behalf. The results support the interpretation that major MNCs collude with governments in the developing world to circumvent the monitoring of World Bank project performance and lobby on behalf of loan disbursements that are unjustifiable in terms of the achievement of project objectives.

\section{CONCLUSIONS}

The World Bank is different in important respects from its sister institution, the IMF, which subjects the implementation of World Bank projects to a different pattern of informal governance. We present evidence that is consistent with a

24. Table A25 presents results that include interactions with project size. All UN Votes remains the only significant geopolitical factor, but as figure A8 indicates, its effect is decreasing in project size and is insignificant for most of the range of projects.

25. Regressions using the same range of geopolitical variables and Evaluation as the dependent variable yield insignificant results, with the sole exception of UNSC Membership, which is significant at the $10 \%$ level in one specification. See table A27. pervasive pattern of lobbying by multinational corporations to encourage the Bank to make disbursements that are not justified by project performance. In contrast, we find no evidence that the participation or presence of multinationals improves the most objective measures of project outcomes. MNCs do not appear to assist the Bank in promoting development, but they appear to interfere with its evaluation and enforcement efforts. The effect is to undermine the incentives for borrowing countries to achieve project objectives and to comply with World Bank environmental and human rights mandates.

The evidence that we present is statistical - we do not have a proverbial "smoking gun"- but we are able to use a series of tests to refine our inferences about the mechanisms that are generating the pattern we see and to reject alternative explanations. We start with a set of firms that have incentives to lobby for the release of project funds, which are contractors on those particular projects, and we show that their presence is associated with extraordinary disbursements. We then disaggregate these firms by country of origin, and find that it is only the US and Japanese firms that demonstrate this effect. This strongly suggests a political interpretation. If not for the fact that US and Japanese firms enjoy privileged access to their respective policy networks, why should projects that employ those firms be treated preferentially?

We further refine our hypotheses by focusing on contractors that take on management responsibilities, which theoretically have the strongest incentives to seek to influence disbursements. As expected, the effect of management contractors is substantially stronger than the effect of contractors that do not have these responsibilities. This appears to indicate that we have identified the correct mechanism. Again, only US 
and Japanese firms exhibit the effect, and the effects are substantially stronger than the corresponding effects for all contractors. Another way to probe the mechanism is to test for additional observable implications, and we do this by using Evaluations as a dependent variable. The mechanism that we propose indicates that unjustified disbursements should be associated with inflated evaluations, and we find that MNC contractors (and particularly those with management responsibilities) are indeed associated with inflated evaluations. On the other hand, an alternative explanation for our findings is that MNC contractors improve project performance. We find that this is not the case. All of these results are robust to country and year fixed effects, which dispenses with alternative explanations based on fixed country-level characteristics or contemporaneous shocks.

These analyses have focused on tightly identifying the mechanism that drives our results, but our next set of results expands their substantive interpretation. Our argument suggests that not only contractors may be interested in World Bank projects; a wide range of multinationals that do not receive project funds may benefit from Bank projects that affect their business strategies. These firms also have incentives to lobby for disbursement, because disbursing the funds makes progress on a particular project more likely, and they do not internalize the Bank's reasons for withholding disbursement. We find that when countries receive larger shares of investments from major MNCs, they receive more excess disbursements. Again, this result holds only for investments by US and Japanese firms, which strongly suggests that a political mechanism is at work. To further narrow the possible interpretations of this result, we use aggregate FDI as a placebo test, finding no significant effects. This indicates that the effects that we attribute to MNC political activity are not due to some other factor associated with variations in FDI, and that the effect is due to the presence of large MNCs rather than smaller investors.

Another alternative explanation for our findings is that MNC investment proxies for other US interests, but we find little evidence of geopolitical influences on disbursement or project evaluation. We tested for a wide range of hypotheses drawn from the literature, seeking evidence of effects of proxies for US interests that previously have been shown to affect IMF lending, conditionality, or enforcement of conditionality, or World Bank lending. We found scant evidence to support these hypotheses in the evaluation and disbursement of World Bank projects. We attribute this striking difference from the findings of previous studies to the special features of World Bank projects, which, while very important in the aggregate, tend to be small scale in particular cases. These individual projects are not highly important in terms of in- ternational politics, but they may be highly salient to particular firms.

These findings should not be interpreted to mean, however, that US informal influence is not considerable in the patterns that we see. We find effects on project evaluation and disbursement for investments by US and Japanese multinationals, and little evidence of effects for investments by multinationals from other countries. This suggests that the powerful informal policy networks of the two leading shareholders play a critical role in facilitating the influence of US and Japanese multinationals. This is consistent with the asymmetric pattern of influence enjoyed by international civil society actors in the World Bank generally: US NGOs have tremendous advantages over similar organizations based in other countries. Furthermore, when it is possible to show that such groups exert influence, it is usually because they have successfully lobbied the US government- the executive branch, the legislative branch, or both-and the Treasury has deployed its policy network to translate their political demands into informal influence. In short, the World Bank's major shareholders are not unitary actors, and firms based in those countries are able to capitalize on the informal influence of their states.

\section{ACKNOWLEDGMENTS}

This article has benefited from comments and feedback from participants at the ISA Workshop on Informal Governance 2014, the annual meeting of APSA 2014 and 2015, the annual meeting of IPES 2014, the annual conference on the Political Economy of International Organizations 2015, seminar participants at Yale University, Washington University in St. Louis, Stanford University, and the University of Rochester. We are grateful to Sarah Bermeo, Stephen Chaudoin, Christopher Kilby, David Lake, Helen Milner, Daniel Nielson, and three anonymous reviewers for helpful comments and suggestions on earlier versions of the paper. We would also like to thank Jonathan Bennett, Alice Gindin, Justine King, Elizabeth Klinger, Katharine McCorkle, Nilakshi Mukherjee, Aaron Schaffer, and Ephraim Shimko for their assistance in coding data.

\section{REFERENCES}

Barnett, Michael, and Martha Finnemore. 2004. Rules for the World: International Organizations in Global Politics. Ithaca, NY: Cornell University Press.

Barro, Robert J., and Jong-Wha Lee. 2005. "IMF Programs: Who Is Chosen and What Are the Effects?" Journal of Monetary Economics 52 (7): 1245-69.

Baumgartner, Frank R., and Beth L. Leech. 2001. "Interest Niches and Policy Bandwagons: Patterns of Interest Group Involvement in National Politics." Journal of Politics 63 (4): 1191-1213. 
118 / Corporate Influence in World Bank Lending Rabia Malik and Randall W. Stone

Boehmke, Frederick J., Sean Gailmard, and John W. Patty. 2013. “Business as Usual: Interest Group Access and Representation across PolicyMaking Venues." Journal of Public Policy 33 (1): 3-33.

Broz, J. Lawrence, and Michael Brewster Hawes. 2006. "Congressional Politics of Financing the International Monetary Fund." International Organization 60 (2): 367-99.

Clegg, Liam. 2013. Controlling the World Bank and IMF: Shareholders, Stakeholders, and the Politics of Concessional Lending. London: Palgrave Macmillan.

Copelovitch, Mark S. 2010. The International Monetary Fund in the Global Economy: Banks, Bonds, and Bailouts. Cambridge: Cambridge University Press.

Denizer, Cevdet, Daniel Kaufmann, and Aart Kraay. 2013. "Good Countries or Good Projects? Macro and Micro Correlates of World Bank Project Performance." Journal of Development Economics 105:288-302.

Dreher, Axel, Jan-Egbert Sturm, and James Raymond Vreeland. 2009. "Development Aid and International Politics: Does Membership on the UN Security Council Influence World Bank Decisions?" Journal of Development Economics 88 (1): 1-18.

Dreher, Axel, and Roland Vaubel. 2004. "The Causes and Consequences of IMF Conditionality." Emerging Markets Finance and Trade 40 (3): 26-54.

Gilpin, Robert. 1975. US Power and the Multinational Corporation: The Political Economy of Foreign Direct Investment, vol. 2. New York: Basic.

Gould, Erica R. 2003. "Money Talks: Supplementary Financiers and International Monetary Fund Conditionality." International Organization 57 (3): 551-86.

Helpman, Elhanan, Marc J. Melitz, and Stephen R. Yeaple. 2004. "Export versus FDI." American Economic Review 94 (1): 300-316.

Independent Evaluation Group. 2006. Engaging with Fragile States: An IEG Review of World Bank Support to Low-Income Countries under Stress. Washington, DC: World Bank.
Keck, Margaret E., and Kathryn Sikkink. 1998. Activists beyond Borders: Advocacy Networks in International Politics, vol. 6. Cambridge: Cambridge University Press.

Kilby, Christopher. 2009. "The Political Economy of Conditionality: An Empirical Analysis of World Bank Loan Disbursements." Journal of Development Economics 89 (1): 51-61.

Kilby, Christopher. 2013. "An Empirical Assessment of Informal Influence in the World Bank." Economic Development and Cultural Change 61 (2): 431-64.

Krasner, Stephen D. 1978. Defending the National Interest: Raw Materials Investments and US Foreign Policy. Princeton, NJ: Princeton University Press.

Lipscy, Phillip Y. 2015. "Explaining Institutional Change: Policy Areas, Outside Options, and the Bretton Woods Institutions.” American Journal of Political Science 59 (2): 341-56.

Nielson, Daniel L., and Michael J. Tierney. 2003. "Delegation to International Organizations: Agency Theory and World Bank Environmental Reform." International Organization 57 (2): 241-76.

Oatley, Thomas, and Jason Yackee. 2004. "American Interests and IMF Lending." International Politics 41 (3): 415-29.

Stone, Randall W. 2002. Lending Credibility: The International Monetary Fund and the Post-Communist Transition. Princeton, NJ: Princeton University Press.

Stone, Randall W. 2004. "The Political Economy of IMF Lending in Africa." American Political Science Review 98 (4): 577-91.

Stone, Randall W. 2008. “The Scope of IMF Conditionality." International Organization 62 (4): 589-620.

Stone, Randall W. 2011. Controlling Institutions: International Organizations and the Global Economy. Cambridge: Cambridge University Press.

Thacker, Strom C. 1999. “The High Politics of IMF Lending." World Politics 52 (1): 38-75.

Woods, Ngaire. 2006. The Globalizers: The IMF, the World Bank, and Their Borrowers. Ithaca, NY: Cornell University Press. 